\title{
Food borne infection by a Norwalk like virus (small round structured virus)
}

\author{
TERENCE RIORDAN, JOHN CRASKE, JEANNE L ROBERTS, ALAN CURRY \\ From the Public Health Laboratory, Withington Hospital, Manchester M20 8LR
}

SUMMARY Two outbreaks of gastrointestinal illness with identical symptoms occurred in parties attending banquets on consecutive evenings at a large hotel. The illness was typical of epidemic winter vomiting disease. Small round structured viruses resembling those seen in the Norwalk Ohio outbreak were identified by electron microscopy in stools of victims from one episode. One food handler was found to be excreting the virus, and there was evidence of a poor standard of hygiene in the kitchen. A food history analysis showed the illness to be significantly associated with eating cold cooked ham.

Amid the range of illnesses known loosely as nonbacterial gastroenteritis there is a clinical entity described by Zahorsky over 50 years ago as winter vomiting disease.' This has an incubation period of 24-48 $\mathrm{h}$ and usually presents with acute onset of abdominal pain and vomiting or diarrhoea, or both. The illness affects all age groups, is of short duration, and is rarely severe enough to result in admission to hospital, even in the elderly. The disease was shown to be transmissible to volunteers by means of filtrates of faeces obtained from victims in the acute stage of illness. ${ }^{23}$ Although several morphologically different viruses have been shown by electron microscopy in the stools of victims in different outbreaks, the evidence for a pathogenic role is strongest for viruses resembling those seen in the Norwalk Ohio outbreak. ${ }^{4}$

Infection with Norwalk like viruses occurs not only as sporadic cases and family clusters but also as large outbreaks. ${ }^{5}$ The epidemiology of such outbreaks is not fully understood. As yet there is no evidence that Norwalk like virus is a zoonosis and we therefore have to assume that the source of all Norwalk virus outbreaks is a human excreter. There appear to be two main modes of transmission: firstly, direct case to case spread such as in a family or a closed community; and, secondly, outbreaks in which there is a common environmental source. Both water borne ${ }^{67}$ and food borne outbreaks due to Norwalk like virus have been described. Some of the food borne outbreaks have been associated with shellfish such as oysters. ${ }^{8-10}$ It is assumed that the oysters are contaminated on the sea bed by human

Accepted for publication 30 March 1984 sewage containing virus. There have also been food borne outbreaks not involving shellfish in which direct contamination of food by a food handler excreting virus has been implicated." 12 Although this has been infrequently documented, we believe it to be an important mode of transmission and report our own experience of such an outbreak.

\section{Outbreak of infection}

In January 1983 persons attending two banquets held on successive evenings at a large hotel reported that they had subsequently been ill. At the first function 50 of 80 guests $(62 \%)$ were ill and at the second 80 of $140(57 \%)$ were ill. The illnesses reported in the two incidents appeared to be identical. The mean and median incubation periods of both incidents were $44 \mathrm{~h}$. Nausea, vomiting, abdominal pain, and diarrhoea were the commonest symptoms; headache and fever were less common features (Table 1). The duration of illness ranged from six to $72 \mathrm{~h}$, median $48 \mathrm{~h}$.

\section{MICROBIOLOGICAL INVESTIGATIONS}

No food remained for examination from either function. Stool samples were obtained from nine victims of the first incident and 11 allegedly symptomless kitchen staff. Stools were not available from victims of the second function. All samples were negative for bacterial pathogens, including salmonellae, shigellae, Campylobacter sp, Staphylococcus aureus, Clostridium perfringens, and Bacillus cereus. All faecal specimens from the outbreak were stored at $+4^{\circ} \mathrm{C}$ until they were prepared for examination by electron microscopy, which was usually within $24 \mathrm{~h}$ 
Table 1 Characteristics of illness

\begin{tabular}{ll}
\hline Symptoms & No $(\%)$ reporting symptoms \\
\hline Nausea & $42(76)$ \\
Abdominal pain & $41 \quad 75)$ \\
Diarrhoea & $36(65)$ \\
Vomiting & $34 \quad 62)$ \\
Shivering & $33 \quad 60)$ \\
Headache & $30(55)$ \\
Fever & $21 \quad(38)$ \\
Total ill & $55(100)$ \\
\hline
\end{tabular}

of receipt by the laboratory.

Electron microscopy for viruses was performed as follows. Twenty per cent faecal suspensions in Hanks' phosphate buffered saline, with bicarbonate, were centrifuged at $1500 \mathrm{~g}$ for $15 \mathrm{~min}$ at $+8^{\circ} \mathrm{C}$ (clarification spin). Two millilitres of supernatant was transferred to a polycarbonate ultracentrifuge tube and spun at $65000 \mathrm{~g}$ for $1 \mathrm{~h}$ at $+8^{\circ} \mathrm{C}$. The supernatant from the ultracentrifuge spin was tipped off and the pellet was resuspended in the small volume of fluid remaining. Virus was adsorbed on to Formvar-carbon coated grids, stained with $3 \%$ phosphotungstic acid ( $\mathrm{pH} 6$ to $6 \cdot 5)$, and examined at 63000 magnification in an AEI (Kratos) EM801 electron microscope. With this technique morphologically identical viruses were seen in stools of $3 / 9$ victims of the first incident and 1/11 kitchen staff. The virus seen was found infrequently in small groups (three to about 30 particles) or as individual or pairs of virus particles. The virion was about $32 \mathrm{~nm}$ in diameter and possessed a ragged or fuzzy edge (Fig. 1).

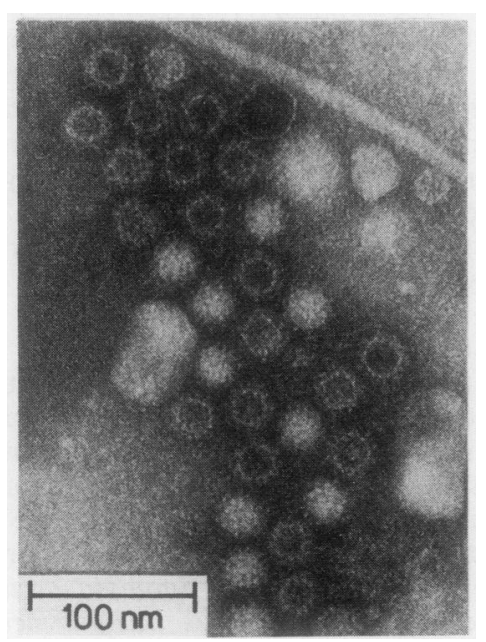

Fig. 1 Group of Norwalk like virus particles in the faeces of a victim. This relatively large group of viruses shows both "empty" and complete particles.

\section{ENVIRONMENTAL INVESTIGATIONS}

The menus for the two functions were examined. Shellfish was not on either menu and there was no item common to the two menus. The hotel concerned had only recently opened. When visited by the local health department one week after the incidents, the kitchen was found to be too small for the workload undertaken and hand wash basins were badly sited. The staff toilets were dirty and neither soap nor paper towels was available. None of the kitchen staff admitted to any recent gastrointestinal illness.

\section{EPIDEMIOLOGICAL INVESTIGATIONS}

Questionnaires requesting details of illness, if any, and food and drinks consumed at the banquet were circulated to all those attending the second function. Replies were received from 79, of whom 55 had been ill and 24 had not. The epidemic curve was plotted (Fig. 2), food history analysis was performed, and food specific attack rates were determined (Table 2). A variety of alcoholic and soft drinks was consumed, but none with sufficient frequency to merit analysis. The only food significantly associated with illness was cold cooked ham ( $p$ $<0.01)$.

\section{Discussion}

The length of the incubation period $(44 \mathrm{~h})$ and the clinical illness with both vomiting and diarrhoea as prominent features, suggested a viral gastroenteritis of the winter vomiting disease type. The finding of small round structured viruses (Norwalk like viruses) in $3 / 9$ stools of victims is compatible with this. The relatively low positive rate is explained in

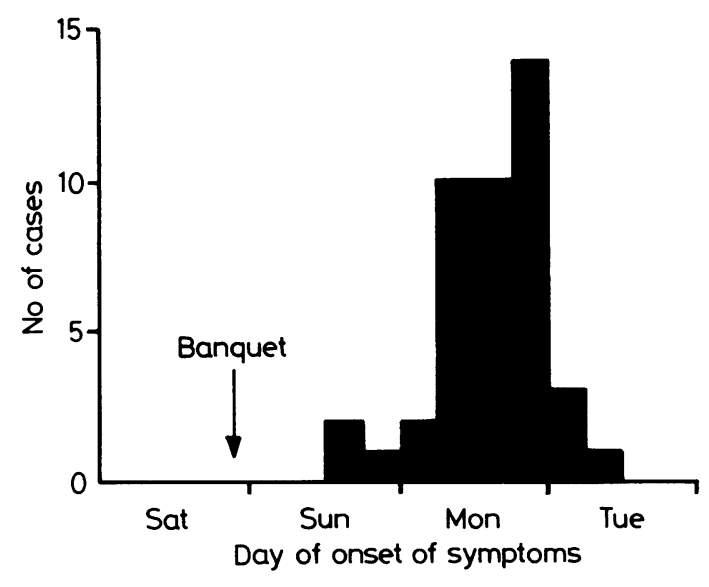

Fig. 2 Epidemic curve for second banquet. 
Table 2 Food history analysis for the second banquet

\begin{tabular}{|c|c|c|c|c|c|c|c|}
\hline \multirow[t]{2}{*}{ Food } & \multicolumn{3}{|c|}{ No of persons eating food } & \multicolumn{3}{|c|}{ No of persons not eating food } & \multirow[t]{2}{*}{$\chi^{2}$ test } \\
\hline & Ill & Not ill & Attack rate (\%) & Ill & Not ill & Attack rate (\%) & \\
\hline Ham & 45 & 13 & $77 \cdot 6$ & 10 & 11 & $47 \cdot 6$ & $p<0.01$ \\
\hline Turkey & 35 & 12 & $74 \cdot 4$ & 20 & 12 & 62.5 & NS* \\
\hline Beef & 42 & 15 & $73 \cdot 6$ & 13 & 9 & $59 \cdot 0$ & NS \\
\hline Coleslaw & 31 & 11 & 73.8 & 24 & 13 & $64 \cdot 8$ & NS \\
\hline Potato salad & 33 & 11 & 75.0 & 22 & 13 & 63.0 & NS \\
\hline Russian salad & 19 & 6 & $76 \cdot 0$ & 36 & 18 & $66 \cdot 7$ & NS \\
\hline Chicken curry & 20 & 11 & $64 \cdot 5$ & 25 & 13 & 65.7 & NS \\
\hline Rice & 18 & 8 & $69 \cdot 2$ & 37 & 16 & 69.0 & NS \\
\hline Fruit salad & 8 & 1 & $88 \cdot \overline{8}$ & 47 & 23 & $67 \cdot 1$ & NS \\
\hline Cream & 9 & 2 & $81 \cdot 8$ & 46 & 22 & $67 \cdot 6$ & NS \\
\hline Gateau & 35 & 15 & $70 \cdot 0$ & 20 & 9 & 68.96 & NS \\
\hline
\end{tabular}

${ }^{*} \mathrm{NS}=$ not significant

part by the inherent insensitivity of electron microscopy and also by the fact that samples were obtained three to four days after the onset of illness. Although stool samples were not available from the second incident, the timing and location, together with the indistinguishable incubation period and clinical illness, are highly suggestive of a common agent.

The explosive onset ( $84 \%$ in the second incident became ill within $24 \mathrm{~h}$ ) and high attack rates favour a common source. There was no evidence of this being water borne. As regards a food borne source, neither menu had included shellfish. In the second incident consumption of cold cooked ham was significantly associated with illness.

Although little is known about the heat sensitivity of Norwalk like viruses, they would be unlikely to survive cooking of the hams. We believe that the ham was contaminated after cooking by a food handler excreting virus and that a similar event occurred with some item(s) on the menu of the first banquet. It was not possible to establish which food handler had sliced and served the ham. Despite the denial of any illness among food handlers, laboratory investigations showed that at least one was excreting virus. Because of the delay in obtaining specimens and the insensitivity of electron microscopy, it is possible that several food handlers were infected and excreting virus over the period of the outbreak. A similar explanation has been postulated in other outbreaks concerning Norwalk like viruses. ${ }^{112}$ There is, at present, no appropriate technique for identifying viruses in food, so that incrimination of a food source has to be on epidemiological grounds.

In outbreaks of salmonella food poisoning food handlers are often found to be excreting the salmonella serotype concerned. They are usually the victims rather than the source of the infection, however, salmonellosis being essentially a zoonosis. Norwalk like virus infection is in striking contrast to this since it is apparently confined to humans. It is prevalent in the community so that food handlers are at risk of acquiring the infection, and because the illness can be mild they may remain at work. In the acute stage of illness they are potentially a major source of infection, virus being excreted in both faeces and vomit. ${ }^{13}$ Contamination of food could occur either from faecal contamination on hands or possibly even from aerosols associated with vomiting. The infective dose appears to be very low, so that even light contamination might result in infection. It is clear that in food borne outbreaks, other than those associated with shellfish, control measures should be directed towards improving standards of hygiene among food handlers.

The ragged edged appearance of the virus shown here is morphologically indistinguishable from the Norwalk agent. ${ }^{4}$ Hence our use of the term Norwalk like virus. Because of their "structured" appearance the Public Health Laboratory Service's Communicable Disease Report describes these viruses as small round structured viruses, and we regard the terms as being interchangeable. This virus is, therefore, distinct from astroviruses and caliciviruses, which show different morphological features, and from featureless small round viruses such as picornaviruses and parvoviruses. ${ }^{14}$ Original American published work on Norwalk stated it to be $27 \mathrm{~nm}$ in diameter, as opposed to the $32 \mathrm{~nm}$ diameter found here. This discrepancy in size may be due to the inherent difficulty of measuring such ragged edged viruses under the electron microscope and also to variation between instruments. This conclusion has support from the International Committee on Taxonomy of Viruses, ${ }^{15}$ which has included Norwalk virus as a possible member of the caliciviridae. The caliciviridae, among other characteristics, have a diameter of 35 to $39 \mathrm{~nm}$. In addition, Caul and Appleton ${ }^{14}$ state that the Norwalk group of viruses have a diameter of 30 to $35 \mathrm{~nm}$. 
We thank Dr AE Jones and Mrs $K$ Johnson of the Manchester Environmental Health Department for supplying details of the outbreak and Mrs A Proctor for typing the manuscript.

\section{References}

' Zahorsky J. Hyperemesis hiemis or the Winter Vomiting Disease. Arch Paediatr 1929;46:391-5.

${ }^{2}$ Dolin R, Blacklow NR, Dupon H, et al. Transmission of acute infectious nonbacterial gastroenteritis to volunteers by oral administration of stool filtrates.J Infect Dis 1971;123:307-12.

${ }^{3}$ Clarke SKR, Cook GT, Egglestone SI, et al. A virus from winter vomiting disease. Lancet $1977 ; \mathrm{i}: 409-11$.

${ }^{4}$ Kapikian AZ, Greenberg HB, Wyatt RG, Kalica AR, Chanock RM. The Norwalk group of viruses-agents associated with epidemic viral gastroenteritis. In: Tyrell DAJ, Kapikian AZ, eds. Virus infections of the GI tract. New York: Marcel Dekker, 1982:147-77.

s Kaplan JE, Gary GW, Baron RC, et al. Epidemiology of Norwalk gastroenteritis and the role of Norwalk virus in outbreaks of acute nonbacterial gastroenteritis. Ann Int Med 1982;96:756-61.

- Taylor JW, Gary GW, Greenberg HB. Norwalk related gastroenteritis due to contaminated drinking water. Am J Epidemiol 1981;114:584-92.

' Baron RC, Murphy FD, Greenberg HB, et al. Norwalk related illness: an outbreak associated with swimming in a recreational lake and secondary person to penson transmission. Am J Epidemiol 1982;115: 163-72.

${ }^{8}$ Grohmann GS, Greenberg HB, Welch BM, Murphy AM. Oyster-associated gastroenteritis in Australia. The detection of Norwalk virus and its antibody by immune electron microscopy and radioimmunoassay. J Med Virol 1980;6:11-9.

${ }^{9}$ Gunn RA, Janowski HT, Lieb S, Prather EC, Greenberg HB. Norwalk virus gastroenteritis following raw oyster consumption. Am J Epidemiol 1982;115:348-51.

${ }^{10}$ Gill ON, Cubitt WD, McSwiggan DA, Watney BM, Bartlett CLR. Epidemic of gastroenteritis caused by oysters contaminated with small round structured viruses. $\mathrm{Br}$ Med $J$ 1983;287: 1532-4.

" Griffin MR, Sorowiec JJ, McCloskey DI, et al. Foodborne Norwalk virus. Am J Epidemiol 1982;115:178-84.

12 Pether JVS, Caul EO. An outbreak of food borne gastroenteritis in two hospitals associated with a Norwalk like virus. J Hyg (Camb) 1983;91:343-50.

${ }^{13}$ Greenberg HB, Wyatt RG, Kapikian AZ. Norwalk virus in vomitus. Lancet 1979; i: 55.

${ }^{14}$ Caul EO, Appleton H. The electron microscopical and physical characteristics of small round human fecal viruses: An interim scheme for classification. $J$ Med Virol 1982;9:257-65.

${ }^{15}$ Matthews REF. Classification and nomenclature of viruses. 을 Intervirology 1982;17:1-200.

Requests for reprints to: Dr T Riordan, Public Health Laboratory, Withington Hospital, Manchester M20 8LR, England. 